\title{
DISTRIBUSI PENDAPATAN KESEJAHTERAAN MENURUT KONSEP EKONOMI ISLAM
}

\author{
An'im Fattach \\ Prodi Manajemen, Fakultas Ekonomi, Universitas Islam Lamongan \\ Jl. Veteran No.53A Lamongan \\ Telp. ( 0322 ) 324706, Faks. ( 0322 ) 324706 \\ Email :jpim@unisla.ac.id
}

\begin{abstract}
Islamic Economics with the idea of giving the economy the principles of life in a relationship with each other. In it contains the direction and at the same time demand that his followers do your best and avoid action that is considered a sin. Islamic economics does not just contain about sets of rules but provides a guarantee for improved welfare. In this article, the authors intend to reveal the clarity of the distribution of income: welfare according to the concept of Islamic economics. Islam considers that economic prosperity is not solely economic problems of distribution of material, but also involves an element of non-material and other fields. Economic welfare can be run in conjunction with welfare in other fields. Islamic economic demands for the overall running of the teachings of Islam in all aspects of life. The consequence of this concept is the well-being should be viewed as a manifestation of God's command to his servant. So that the welfare of the continuing e orts of mankind to do good, both to God and to fellow human beings.
\end{abstract}

Keywords: Distribution, Income, Welfare, Islamic Economic

\section{PENDAHULUAN}

Kesejahteraan menjadi bagian penting bagi suatu negara, Permasalahan yang dihadapi negara-negara yang sedang berkembang adalah kesejahteraan warga negaranya. Bahkan, didirikannya atau dibentuknya sebuah negara salah satu tujuannya adalah dalam rangka mewujudkan kesejahteraan bagi masyarakatnya. Berbagai cara, metode, aturan, alat, pendekatan, ataupun kebijakan telah dipilih, ditempuh dan dilakukan oleh sebuah negara dalam rangka untuk mencapai tujuan tersebut. Makanya pemimpin pada suatu negara diminta untuk serius dalam mencapai kemajuan dari negara.
Berbagai nilai dan institusi sosial tersebut dapat menjadi instrumen bagi terciptanya kehidupan yang lebih teratur dan lebih baik. Demikian juga dengan dorongan untuk membentuk negara. Negara dibutuhkan dan dibentuk untuk mewujudkan ketertiban dan kehidupan yang lebih baik dan layak yang juga biasa disebut kesejahteraan. Dengan demikian, kesejahteraan menjadi harapan cita-cita bagi setiap individu dan setiap masyarakat, bahkan setiap negara. Kondisi kehidupan bermasyarakat dan bernegara yang sejahtera menjadi sesuatu yang ideal (Soetomo, 2014).

Indonesia adalah termasuk diantara negara yang menjadikan atau memimpikan 
ada kesejahteraan yang ingin dirasakan, oleh sebabnya kesejahteraan bangsanya sebagai tujuan yang final bagi bangsa ini dari zaman kemerdekaan sampai sekarang ini. Bagaimana tidak, Indonesia dengan kekayaan sumber daya alamnya yang melimpah belum bisa mensejahterakan masyarakat dan bangsa sendri. Menjadikan tantangan tersendiri bagi bangsa/negara dalam menyongsong mimpi yang ingin direalitaskan seperti yang dirasakan oleh negara-negara maju di Eropa. Kesulitan demi hari dan tahun harus menjadi pelajaran berharga yang tidak bisa kesampingkan dalam menyikapi persoalan yang ada pada saat sekarang. Indonesia harus bisa bermimpi seperti negara maju yang ada di Asia, Rumusan kesejahteraan yang dituangkan di dalam pembukaan UUD 1945, selain itu komitmen tersebut juga dijabarkan di dalam batang tubuhnya, yakni Bab XIV pasal 33 tentang perekonomian nasional dan kesejahteraan sosial (Dampriyanto, 2009).

Umat Islam yakin bahwa Allah SWT menciptakan langit dan bumi, dan segala apa yang ada diantara keduanya untuk kesejahteraan umat manusia, dan untuk itu manusia harus memanfaatkannya seoptimal mungkin tanpa menimbulkan kerusakan dan ketidakadilan dimuka bumi. Selanjutnya, umat Islam yakin/percaya bahwa Allah SWT menjamin rezeki setiap makhluk-Nya. Tidak ada yang sia-sia dalam penciptaan Allah SWT.

Sejahtera dalam menggapainya tidak bisa dengan teori dan doa, namun hal tersebut dipraktekan atau diusahakan untuk mencapainya makanya manusia dituntut untuk memamfaatkan kemampuannya dan belajar dari kekurangan yang ada dalam diri.
Manusia sebagai khalifah dimuka bumi dilarang keras untuk meminta-minta secara tersembunyi ataupun di dalam bentuk terang-terangan.

Oleh karenanya, ciri dari tercapainya tujuan tersebut menurut Bung Karno dalam buku Lahirnya Pancasila adalah tidak adanya kemiskinan (Sunarso Hs. dan Joh. Mardimin, 1996). Untuk memastikannya, para pendiri bangsa ini menegaskannya dalam Pasal tentang fakir miskin dan anakanak terlantar yang dipelihara oleh Negara. Namun demikian, hingga saat ini kesejahteraan yang dicita-citakan belumlah tercapai bahkan masih jauh dari harapan yang diinginkan oleh masyarakatnya maupun oleh pendiri bangsa ini. hal tersebut tergambar dari kehidupan masyarakat sehari-hari, pada hari ini masih banyak masyarakat meminta-minta dijalanan bahkan mereka membawa buah hati untuk melakukan pekerjaan tersebut. Kondisi inilah yang kemudian melahirkan konsep ketimpangan atau kesenjangan ditegahtengah masyarakat bahkan efek dari itu semua menjadikan karakter yang tahan banting terhadap kepeduliannya kepada orang di sekitarnya. Kesenjangan terjadi apabila 20 persen penduduk yang tergolong kaya meraih lebih dari 50 persen GNP. Di Indonesia, kesenjangan spasial terjadi antara desa dan kota, antara Jakarta dan luar Jakarta, antara Jawa dan luar Jawa, antara Indonesia bagian barat dan Indonesia bagian timur. Akhirnya muncul kesadaran bahwa penerapan strategi growth first distribution later tidak sesuai untuk negara-negara berkembang (Gunawan Sumodiningrat, 2009). 
Kesejahteraan telah diasumsikan sebagai sebuah pertumbuhan yang tinggi dalam pembangunan ekonomi. Oleh sebabnya ada sebuah negara yang disebut negara berkembang dan negara maju. Pendekatan ini telah banyak membuat negara berhasil mencapainya. Indikator keberhasilan tersebut adalah meningkatnya akumulasi kapital dan pendapatan per kapita. Tetapi tidak bisa dipungkiri juga, bahwa pendapatan per kapita pada masyarakat atau negara tidak menjamin kesejahteraan masyarakat atau bangsa. Ternyata kenaikan pendapatan per kapita mungkin tidak menaikan standar hidup rill masyarakat. Bisa saja terjadi bahwa sementara pendapatan nyata per kapita meningkat akan tetapi konsumsi perkapita merosot. Masyarakat mungkin meningkatkan tingkat tabungan mereka atau bahkan pemerintah sendiri menghabiskan pendapatan tersebut untuk keperluan militer atau keperluan lain. Ada kemungkinan lain yang menyebabkan masyarakat tetap miskin kendati ada kenaikan dalam pendapatan nasional nyata jika pendapatan itu hanya dinikmati oleh beberapa gelintir orang kaya dan tidak oleh banyak orang miskin. Namun demikian, keberhasilan ini hanya dinikmati oleh pemilik modal dan kelompok elit nasional.

Seiring dengan semangat umat Islam untuk berusaha menerapkan ajaran agamanya, munculah kajian tentang kesejahteraan dalam perekonomian yang berbasiskan Ekonomi Islam. Paradigma ini menjelaskan bahwa kesejahteraan masyarakat akan dapat tercapai bila seluruh aktivitas manusia berlandaskan Ekonomi syariah atau Ekonomi Islam.
Meskipun belum semua meyakini akan keampuhannya dalam menyelesaikan masalah-masalah perekonomian, sosial, politik, hukum, budaya, dan berbagai masalah alam, namun paradigma ini memberikan pemahaman yang sempurna tentang alam semesta, yakni : langit, bumi, dan segala isinya termasuk manusia sebagai khalifah di dalamnya.

Dalam kehidupan memang akan terjadi perbedaan dan kesenjangan ekonomi atau rezeki diantara pelaku ekonomi, karena hal tersebut merupakan sunnatullah. Kondisi inilah yang secara religius akan menciptakan mekanisme ekonomi, bagi siapa mempunyai kelebihan rezki yang di berikan allah SWT menolong saudara/individu yang mempunyai kekurangan rezki atau harta, secara umum, Islam mengarahkan mekanisme berbasis moral spritual di dalam pemiliharaan keadilan sosial pada setiap aktivitas ekonomi. Latar belakangnya karena ketidakseimbangan kekayaan adalah hal yang mendasari hampir semua konflik individu maupun sosial. Hal tersebut akan sulit dicapai tanpa adanya keyakinan pada prinsip moral dan sekaligus kedisiplinan dalam mengimplementasikan konsep moral tersebut. Ini adalah fungsi dari menterjemahkan konsep moral sebagai faktor endogen dalam perekonomian, sehingga etika ekonomi menjadi hal yang sangat membumi untuk dapat mengalahkan setiap kepentingan pribadi.

Ekonomi Islam sesungguhnya secara inheren merupakan konsekuensi logis dari kesempurnaan Islam itu sendiri, Islam harus dipeluk secara kafah dan komprehensif oleh umatnya. Islam menuntut pada pada 
umatnya untuk mewujudkan keislamannya dalam seluruh aspek kehidupannya. Sangatlah tidak masuk akal seorang muslim melakukan sholat lima waktu, lalu dalam kesempatan lain ia tidak mampu memberikan sebahagiaan kekayaannya untuk orang lain. Sehingga kesenjangan akan semakin menyempit walaupun tidak bisa dihilangkan sama sekali. Dengan demikian hanya dengan tolong menolong dan saling memberilah, maka kebutuhan manusia itu dapat terpenuhi, karena yang kaya membutuhkan yang miskin dan sebaliknya yang miskin membutuhkan yang kaya (Muhammad Nafik HR, 2009).

Dalam perspektif ide atau gagasan, ternyata konsep kesejahteraan banyak mengadopsi pada paham kapitalisme dan sosialisme (M. Umer Chapra, 2000). Paham ini telah terbukti membawa banyak kegagalan dalam mengantarkan pembangunan untuk mencapai kesejahteraan masyarakatnya. Oleh karena itu, munculah sebuah alternatif konsep kesejahteraan yang mengacu pada nilai-nilai ajaran Ekonomi Islam. Pada saat krisis ekonomi moneter melanda dunia, lembaga-lembaga ekonomi di negara-negara berkembang yang menerapkan mekanisme syariah terbukti dapat bertahan dan bahkan disebagiannya mampu untuk dapat tumbuh dan berkembang. Sehingga berawal dari keberhasilannya ini mulailah banyak dikaji tentang konsep kesejahteraan yang berlandaskan pada ekonomi Islam (M. Lutfi Hamidi, 2003).

Dalam teori-teori ekonomi, nilai-nilai yang ditawarkan ekonomi Islam tergolong hal yang baru. Meskipun pada kenyataannya ajaran Islam memberikan petunjuk- petunjuknya dalam beraktivitas ekonomi tetapi secara bangunan ilmu masih membutuhkan proses untuk menjadi mapan. Muncul dan berkembangnya ilmu ekonomi Islam ini turut memberikan alternatif pemecahan masalah yang berlarut-larut akibat dari mengusung ide atau gagasan kapitalisme maupun sosialisme yang mengalami kegagalan.

Di sisi lain, ajaran Ekonomi Islam memang menuntut para pemeluknya untuk berlaku secara profesional yang dalam prosesnya menampilkan kerapian, kebenaran, ketertiban, dan keteraturan (Didin Hafidudin dan Hendri Tanjung, 2003). Tuntutan inilah yang mendorong untuk menunjukkan tentang bagaimana ekonomi Islam memberikan alternatif dalam kejelasan konsep kesejahteraan tersebut.

Pada karya ilmiah ini dimaksudkan untuk menjelaskan Distribusi pendapatan dan kesejahteraan menurut konsep ekonomi Islam. Didalam pembahasannya akan diuraikan berdasarkan sumber-sumber dari ajaran ekonomi Islam, yakni Al-Qur'an, Hadis, pendapat ulama, dan pendapat ahli ekonomi Islam. Tulisan ini diharapkan dapat menggali berbagai ide atau gagasan tentang kesejahteraan agar dapat memberikan kontribusi dalam memecahkan berbagai permasalahan bangsa dan negara.

\section{Distribusi Pendapatan}

Pengertian distribusi pendapatan menurut Ahli ilmu ekonomi adalah setiap kegiatan menyalurkan barang dan jasa, dan produsen (penghasil) ketangan konsumen (pemakai) yang membutuhkannya. Pengertian distribusi pendapatan, tidak terlepas dari pembahasan mengenai konsep moral ekonomi yang dianut. Di samping itu, 
juga tidak lepas dari model instrumen yang diterapkan individu maupun negara, dalam menentukan sumber-sumber maupun caracara pendistribusian pendapatannya. Dan juga sebetulnya konsep Islam tidak hanya mengedepankan aspek ekonomi, dimana ukuran berdasarkan atas jumlah harta kepemilikan , tetapi bagaimana terdistribusi penggunaan potensi kemanusiaannya, yang berupa penghargaan hak hidup dalam kehidupan. Distribusi harta tidak akan mempunyai dampak kalau tidak ada kesadaran antara sesama manusia akan kesamaan hak hidup.

Untuk itu, dalam menanggapi laju perkembangan pemikiran ini, yang dapat dilakukan adalah : Pertama, mengubah cara pola pikir dan pembelajaran mengenai nilai Islam, dari yang terfokus perhatiannya kematerialistik kepada tujuan yang mengarahkan kesejahteraan umum berbasis pembagian sumber daya dan resiko yang berkeadilan untuk mencapai kemanfaatan yang lebih besar bagi komunitas sosial. Kedua, keluar dari ketergantungan kepada pihak lain, hidup diatas kemampuan pribadi sebagai personal maupun bangsa, melaksanakan kewajiban finansial sebagaimana yang ditunjukan oleh ajaran Islam dann meyakini sungguh-sungguh bahwa dunia saat ini bukan akhir cerita dari segala-galanya, Akan ada kehidupan baru setelah kehidupan di dunia (Masoud Ali Khan, 2005).

Oleh karena itu, di lain pihak prinsip moral Islam mengarahkan kepada kenyataan bahwa pengakuan hak milik harus berfungsi sebagai pembebas manusia dari karakter materialistis. Hanya karena pembebasan itu, manusia bisa mendapatkan kemuliaannya bukan sebaliknya. Dalam Islam hak legitimasi hak milik akan tergantung dan sangat terkait erat kepada pesan moral untuk menjamin keseimbangan, dimana hak pribadi diakui, namun hak kepemilikan tersebut harus bisa berfungsi sebagai nafkah konsumtif bagi diri dan keluarga, berproduksi dan berinvestasi, alat mengapresiasikan kepedulian sosial (zakat, infak, dan sedekah) dan jaminan distribusi kekayaan, menjamin mekanisme kerja di jalan Allah SWT.

Islam menciptakan beberapa instrumen untuk memastikan keseimbangan pendapatan di masyarakat. Seperti zakat dan sedekah misalnya, instrumen ini di kedepankan untuk keseimbangan karena mengingat tidak semua orang mampu terlibat dalam proses ekonomi karena yatim piatu atau jompo dan cacat tubuh. Tetapi harus diingat zakat tidak akan ada sumbernya yang bertumpu pada tiga hal: profit perdagangan, pendapatan, dan gaji pekerja, dan aset perusahaan atau individu. Oleh karena itu, yang perlu di perhatikan adalah aktivitas ekonominya terlebih dahulu, baru dipompa kesadarannya untuk membayarkan zakat (Mustafa Edwin Nasution, 2006).

Dari bahasan normatif di atas, etikonomi untuk distribusi pendapatan atas hak kepemilikan materi atau kekayaan dalam Islam mencerminkan beberapa hal :

a. Pemberlakuan hak kepemilikan individu pada suatu benda, tidak menutupi sepenuhnya akan adanya hak yang sama bagi orang lain.

b. Negara mempunyai otoritas kepemilikan atas kepemilikan individu yang tidak 
bartanggung jawab terhadap hak miliknya

c. Ada hak kepemilikan orang lain dalam hak kepemilikan harta.

d. Konsep kongsi dalam hak yang melahirkan keuntungan materi harus merujuk kepada sistem bagi hasil.

e. Dalam hak kepemilikan berlaku sistem konsep takaful/jaminan sosial jika dalam kelembagaan atau institusi.

Kapitalisme merupakan sebuah sistem organisasi ekonomi yang dicirikan oleh hak milik privat (individu) atas alat-alat produksi dan distribusi (tanah, pabrik-pabrik, kereta api dan sebagainya) dan pemanfaatan untuk mencapai laba dalam kondisi-kondisi yang sangat kompetitif. (Winardi, 1986 ). Lembaga hak milik swasta merupakan elemen paling kokoh dari kapitalisme. Para individu memperoleh perangsang agar aktiva mereka di manfaatkan seproduktif mungkin. Hal tersebut sangat mempengaruhi distribusi kekayaan serta pendapatan karena individu-individu di perkenankan untuk menghimpun aktiva dan memberikannya kepada para ahli waris secara mutlak apabila mereka meninggal dunia.

Dalam ekonomi Islam, kebutuhan memang menjadi alasan untuk mencapai pendapatan minimum. Sedangkan kecukupan dalam standar hidup yang baik (nisab) adalah hal yang paling mendasari dalam sistem distribusi redistribusi kekayaan, setelahnya baru dikaitkan dengan kerja dan kepemilikan pribadi. Haruslah diingat, walaupun setiap individu maupun kolektif (negara) terus berusaha mencapai tingkat kemapaman materi, tetap saja secara sunnatullah akan selalu ada pihak yang difisit dan ada pula pihak yang surplus.
Karena Ekonomi Islam meyakini bahwa ketidakseimbangan materi ditentukan sebagai cobaan hidup manusia, artinya substansi hidup di dunia adalah cobaan, dan menjadi kaya atau menjadi miskin adalah bagian dari cobaan.

Sedangkan standar atau indikator kebutuhan dan batasan yang mendasari sistem distribusi pendapatan Islam adalah maqasid syariah. Sistematika hirarki yang dikembangkan fuqaha dalam memenuhi aspek-aspek tersebut mengacu pada skala prioritas dengan urutan berikut : 1) $A d$ daruriyyah : suatu skala kebutuhan yang berkaitan erat dengan kebaikan dan kepentingan dalam menjalani hidup di dunia dan akhirat, 2) Al-hajjiyyah : suatu skala kebutuhan yang berkaitan erat dengan kemudahan dan penghindaran kesulitan dalam menjalani hidup di dunia dan di akhirat,

3) At-tahsiniyyah : suatu skala kebutuhan yang berkaitan erat dengan kelengkapan dan kecakapan melaksanakan hidup di dunia dan akhirat (Wahbah Zuhaili, 1997).

\section{Distribusi Pendapatan dalam Konteks Rumah Tangga}

Distribusi pendapatan dalam konteks rumah tangga akan sangat terkait dengan terminologi shadaqah di sini bukan berarti sedekah dalam kontek pengertian bahasa indonesia. Karena shadaqah dalam kontek terminologi Alquran dapat dipahami dalam dua aspek yaitu : Pertama, shadaqah wajibah yang berarti bentuk-bentuk pengeluaran rumah tangga yang berkaitan dengan instrumen distribusi pendapatan berbasis kewajiban. Kedua : Shadaqah Nafilah, yang berarti bentuk-bentuk pengeluaran rumah tangga yang berkaitan 
dengan instrumen distribusi pendapatan berbasis amal kreatif seperti sedekah (Mohzer Kahf, 1991).

Penekanan dalam konsep distribusi pendapatan adalah adanya hak Allah dan Rasul-Nya serta orang/muslim lain dari setiap pendapatan seorang muslim. Hal ini juga diarahkan sebagai bentuk dari takaful ijtimai (jaminan sosial) seorang muslim dengan keluarga dan dengan orang lain, sehingga menjamin terjadinya minimalisasi ketidaksetaraan pendapatan (uniequality income) dan keadilan sosial (sosial justice). Kejelasan mengenai aspek-aspek ekonomi terminologi shadaqah dalam konteks distribusi pendapatan rumah tangga.

Pertama: Kewajiban shadaqah wajibah (wajib dan khusus dikenakan bagi orang muslim) adalah

Nafaqah: kewajiban tanpa syarat dengan menyediakan semua kebutuhan pada orang-orang terdekat yakni anak dan istri.

Zakat: Instrumen zakat adalah kewajiban seorang muslim untuk menyisihkan sebagian harta miliknya, untuk didistribusikan kepada kelompok tertentu (delapan asnaf). Konsep Islam mempunyai kejelasan mekanisme untuk penerapan ini. Ada dua macam instrumen dalam bentuk zakat yaitu zakat maal dan zakat fitrah.

Udhiyah: Kurban binatang ternak pada saat hari tasyrik perayaan hari raya idul adha. Tarifnya satu ekor kambing perindividu atau sapi dan kerbau untuk tujuh individu. Dilaksanakan setiap tahun sekali.

Warisan: Pembagian aset kepemilikan kepada orang yang ditinggalkan setelah meninggal dunia, ajaran Islam sangat memperhatikan keberlangsungan hidup anak cucu adam. Islam sangat menganjurkan kepada setiap rumah tangga muslim mencapai suatu tingkat kesejahteraan tertentu, agar kehidupan rumah tangga tersebut dan orang-orang yang ditinggalkannya dalam keadaan sejahtera secara ekonomi.

Musaadah: memberikan bantuan kepada orang lain yang mengalami musibah. Dalam hal tersebut, Islam menekankan bahwa materi yang dijadikan objek bantuan (didistribusikan) harus dalam keadaan yang layak, baik dan bagus (proper goods). Dalam pemberiannya, ajaran Islam juga tidak menentukan suatu keadaan ekonomi tertentu, yang ada hanya aturan definitif mengenai semampu dan seikhlasnya bantuan tersebut.

Jiwar: Bantuan yang diberikan berkaitan dengan urusan bertetangga. Perhatian Islam untuk instrumen ini cukup detail. Nabi sendiri menganjurkan untuk selalu memperbanyak kuah dalam memasak sayur, agar dapat berbagi dengan terdekat.

Diyafah: Kegiatan memberikan jamuan terhadap tamu, hal ini juga tidak menentukan kondisi perekonomian tertentu dari rumah tangga muslim Dalam memberikan jamuan, rumah tangga muslim tidak dibenarkan untuk membedakan kualitas jamuan yang diberikan, baik kaya atau miskin. 
Kedua: Instrumen shadaqah nafilah (sunnah dan khusus dikenakan bagi muslim) adalah:

Infak: Sedekah yang dapat diberikan kepada pihak lain jika kondisi keuangan rumah tangga muslim sudah berada di atas nisab.

Akikah: Memotong seekor kambing untuk anak perempuan dan dua ekor kambing untuk anak laki-laki yang baru dilahirkan.

Wa $\boldsymbol{k} \boldsymbol{a} \boldsymbol{f}: \mathrm{Me} \mathrm{m}$ b e r i k a n b a n t u a $\mathrm{n}$ kepemilikannya untuk kesejahteraan masyarakat umum, aset yang diwakafkan boleh dalam bentuk, tanah, rumah, barang ataupun aset keuangan lainnya.

Wasiat: Hak pemberian harta kepada orang lain (1/3 harta) yang didistribusikan setelah si pemberi wasiat meninggal dunia.

Selain itu, distribusi pendapatan dapat pula dilakukan dengan melakukan transaksi pinjam-meminjam atau utang-piutang, sewamenyewa ataupun upah, jual beli, joint venture dan profit /loss sharing. Dalam transaksi tersebut, ada yang berbasis amal karitatif, yaitu: pinjam-meminjam, dan utang piutang. Ada pula yang berbasis bisnis(tijarah), yaitu sewa menyewa, upah, jual beli, joint venture dan profit/loss sharing. Dengan demikian, transaksi berbasis amal karitatif tidak dibenarkan menuntut adanya tingkat pengembalian, sedangkan transaksi lainnya dapat menuntut adanya tingkat pengembalian tertentu (margin dan bagi hasil).

Distribusi Pendapatan dalam Konteks Negara
Prinsip-prinsip ekonomi yang dibangun atas nilai moral Islam mencanangkan kepentingan distribusi pendapatan secara adil. Para ekonom muslim banyak membicarakan objektivitas perekonomian berbasis Islam pada level negara terkait dengan diantaranya, penjaminan di level minimum kehidupan bangsa bagi mereka yang berpendapatan di bawah kemempuan pemenuhan kebutuhan dasar, negara wajib bekerja untuk meningkatkan kesejahteraan materi bagi lingkungan sosial maupun individu dengan pemamfaatan yang sebesarbesarnya atas sumber daya yang tersedia. Maka, negara wajib mengeluarkan kebijakan yang mengupayakan stabilitas ekonomi, kesetaraan, ketenegakerjaan, pembangunan sosial ekonomi, dan lain sebagainya.

Sebenarnya kalangan ekonom barat sendiri sudah banyak melancarkan kritikan pedas terhadap pola yang ada saat ini, misalnya Dudley Seers yang percaya bahwa kriteria pembangunan adalah berkurangnya angka kemiskinan, berkurangnya angka pengangguran, dan meratanya distribusi pendapatan. Jika salah satu dari persoalan tersebut, terutama jika ketiga-tiga memburuk maka tidak dapat dikatakan bahwa negara yang bersangkutan telah mengalami pembangunan sekalipun pendapatan per kapitanya berlipat dua kali. Strategi pembangunan berbasis dari ajaran Islam mengubah paradigma dengan menyajikan beberapa elemen penting yaitu: pertama, seluruh keinginan agen ekonomi tidak dapat diloloskan kecuali telah melewatkan saringan filter. Yang terdiri dua lapis saringan yaitu maslahah syariyyah dan mekanisme harga di pasar. Kedua, agen ekonomi perlu dimotivasi untuk melakukan 
pemuasan kebutuhan dengan tidak membahayakan lingkungan. Ketiga, perlu ada restrukturisasi dalam bidang sosioekonomi dengan tujuan untuk mengurangi konsentrasi kekayaan yang beredar di kalangan tertentu, terus menghapuskan pola konsumsi pamer, konsumtif, dan mereformasi sistem keuangan (Mustafa Edwin Nasution, 2006 ).

Untuk hal tersebut, pembahasan berikut akan mengarah kepada kajian pengalaman pemerintah Islami dalam mengelola sumber daya (manusia dan alam) agar dapat menciptakan nuansa pasar terbuka, terutama keterkaitannya dengan struktur produksi dan dinamika tenaga kerja.

\section{a. Pengelolaan Sumber Daya}

Dalam pengelolaan sumber daya alam yang tersedia, pemerintah (negara) harus mampu mendistribusikan secara baik atas pemanfaatan tanah/lahan dan industri (sumber daya alam). Artinya kesempatan tidak hanya diberikan kepada sekelompok orang untuk menjalankan proses produksi. kebijakan distribusi menganut kesamaan dalam kesempatan kerja, pemanfaatan lahan-lahan yang menjadi sektor publik, pembelaan kepentingan ekonomi untuk kelompok miskin, menjaga keseimbangan sosial dan investasi yang adil dan merata berdasarkan equity dan keseimbangan antar geografis, area, sektor perkotaan dan perdesaan dan lapangan pekerjaan (Mohzer Kahf, 1991). Keterkaitan kebijakan sumber daya dan kewajiban zakat, semata-mata diarahkan agar para pelaku pemerintahan dapat memahami adanya unsur normatif dalam setiap pengumpulan dan pembelanjaan aset kekayaan negara. Godaan terbesar fenomena empiris saat ini adalah perilaku korup yang kerap terjadi pada saat pengumpulan (state collection) dan pembelanjaan (government spending) aset publik.

Di lain pihak, norma yang termaktub pada sejumlah literatur ekonomi juga menyajikan bahwa keberadaan lahan publik pada umumnya berpotensi untuk berlaku sebagai penghambat dalam pencapaian efisiensi, walaupun pada pasar kompetitif sekalipun. Karena lahan publik sudah menjadi bagian dari fungsi utility setiap individu dalam posisi yang istimewa. Jika dibandingkan dengan private good di mana hanya pada porsi tertentu dari total penawaran yang bisa dinikmati secara eksklusif oleh orang tersebut. Sedangkan untuk lahan publik semua total penawaran dapat menyentuh utiliy function setiap orang secara simultan karena memang setiap orang dapat mengkonsumsi dan memamfaatkan secar simultan sejumlah yang dapat ditawarkan dari public goods tersebut (Zafar Iqbal, 1992).

\section{b. Kompetisi Pasar dan Redistribusi Sistem}

Menurut teori ekonomi menyatakan bahwa pasar adalah salah satu mekanisme yang bisa dijalankan oleh manusia untuk mengatasi problem ekonomi yang terdiri atas: produksi, konsumsi, dan didtribusi. Alternatif solusi yang mencuat dalam sejarah peradaban untuk problem ekonomi adalah mekanisme pasar, tradisi dan ekonomi terpimpin. Keberatan terbesar terhadap mekanisme kompetisi pasar adalah bahwa pasar tak lebih sebagai instrumen bagi yang berkuasa untuk mengukuhkan dominasinya terhadap kelas yang kecil/ tertindas. Di lain pihak menurut ekonomi 
liberal meyakini bahwa pasar sebagai instrumen yang penuh geliat konflik pemburu rente dan kelompok kepentingan.

Menurut tradisi pandangan ekonomi klasik dan neo klasik, mekanisme pasar mengimplikasikan adanya persaingan terbuka antara pencari keuntungan. Jika persaingan berlangsung terbuka, keuntungan tiap pelaku secara individu bisa memperoleh keuntungan yang besar (supernormal profit). Karena pemburu rente ini berusaha memaksimalkan keuntungan ekonomi yang bisa mereka peroleh dengan cara menghindari persaingan di pasar. Oleh karena itu, berseberangan kaum marxian, ekonom liberal justru berpendapat bahwa adanya persaingan dalam pasarlah yang menghasilkan distribusi yang adil (Robert Helibroner, 1972).

Namun demikian, kondisi rill market pada saat ini menunjukan adanya ketidakseimbangan distribusi di dalam faktor produksi. Pasar gagal dalam upaya pendistribusian sumber daya. Mereka yang terdidik, berpengalaman, mempunyai keahlian dan modal. Hal tersebut membawa perubahan mekanisme pada pasar, yang kemudian menggiring si pemenang kompetisi untuk semakin kaya dan miskin bertambah miskin.

Pada saat tersebut, pasar tidak akan bisa mengakomodasi ataupun mengembangkan kelompok defisit, perubahan dan sistem pertukaran pada pasar (market exchange) dan kemudian tidak pula memberikan peluang defisit untuk mengembangkan kapabilitasnya. Dari sini, fenomenanya kemudian menunjukan kelompok defisit terus bertambah dari segi kuantitas, kelas menengah (middle class) semakin berkurang dan alhasil gep antara defisit dan surplus terus membengkak (Mabid Ali Al-jarhi dan M. Anas Zarqa, 2005).

\section{Pengertian Kesejahteraan}

Pengertian kesejahteraan menurut kamus bahasa Indonesia berasal dari kata sejahtera yang mempunyai makna aman, sentosa, makmur, dan selamat, terlepas dari segala macam gangguan, kesukaran, dan sebagainya (Poerwadarminto, 1999). Kata sejahtera mengandung pengertian dari bahasa sansekerta "catera" yang berarti payung. Dalam konteks kesejahteraan, "catera" adalah orang yang sejahtera, yakni orang yang dalam hidupnya bebas dari kemiskinan, kebodohan, ketakutan, atau kekhawatiran sehingga hidupnya aman dan tentram, baik secara lahir maupun batin (Adi Fahrudin, 2012).

Kesejahteraan material dan spiritual merupakan tujuan yang ingin dicapai dalam proses pembangunan (Harry Hikmat, 2010). Hal ini menunjukkan bahwa keberhasilan pembangunan haruslah dicapai tidak saja dalam aspek material, tetapi juga dalam aspek spiritual. Ketika sebuah proses pembangunan hanya diarahkan untuk mencapai keberhasilan material maka bisa dipastikan kesejahteraan masyarakat yang diinginkan tidak akan bisa tercapai. Masyarakat akan merasakan kehidupan yang hampa dan tanpa makna meskipun semua fasilitas tersedia.

Kesejahteraan oleh sebagian masyarakat selalu dikaitkan dengan konsep kualitas hidup. Konsep kualitas hidup merupakan gambaran tentang keadaan kehidupan yang baik. World Health Organization mengartikan kualitas hidup sebagai sebuah persepsi individu terhadap kehidupannya di 
masyarakat dalam konteks budaya dan sistem nilai yang ada yang terkait dengan tujuan, harapan, standar, dan juga perhatian terhadap kehidupan. Konsep ini memberikan makna yang lebih luas karena dipengaruhi oleh kondisi fisik individu, psikologis, tingkat kemandirian, dan hubungan sosial individu dengan lingkungannya.

Undang-Undang Nomor 13 tahun 1998 menjelaskan juga tentang arti dari kesejahteraan. Kesejahteraan didefinisikan sebagai suatu tata kehidupan dan penghidupan sosial baik material maupun spiritual yang diliputi rasa keselamatan, kesusilaan, dan ketentraman lahir batin yang memungkinkan bagi setiap warga negara untuk mengadakan pemenuhan jasmani, rohani, dan sosial yang sebaik-baiknya bagi diri, keluarga, serta masyarakat dengan menjunjung tinggi hak dan kewajiban asasi manusia sesuai dengan Pancasila.

Dalam konteks kenegaraan, kesejahteraan digunakan di dalam rangka menunjukkan bahwa pemerintahannya menyediakan pelayanan sosial secara luas kepada warga negaranya. Negara kesejahteraan diartikan sebagai sebuah proyek sosialis demokrat yang dihasilkan oleh perjuangan orang-orang kelas pekerja untuk menciptakan masyarakat yang adil. Ide negara kesejahteraan barat ini dianggap sebagai perubahan yang dilakukan oleh sistem kapitalis menuju kepada aspirasi yang dibawa dalam sistem sosialis.

Di pihak lain, pakar Marxist mengatakan bahwa negara kesejahteraan hanyalah sedikit melebihi usaha untuk mengurangi ekses-ekses yang lebih buruk dari kapitalisme. Mereka mengatakan bahwa negara kesejahteraan sedikitpun bukan merupakan negara sosialis. Hal ini karena di negara kesejahteraan paling maju, sistem ekonomi tetap dimiliki dan dikendalikan oleh kepentingan-kepentingan swasta.

Kelompok yang tidak menyetujui gagasan kapitalisme maupun sosialisme memberikan definisi tersendiri tentang kesejahteraan. Negara kesejahteraan diartikan sebagai sebuah pembentukan sosial yang unik berdasarkan prinsip neomerkantilis. Negara kesejahteraan merupakan konsensus kesejahteraan atau kompromi demokratis sosial. Hal ini disebabkan adanya penyesuaian historis antara kapitalisme dan sosialisme.

Dalam konteks teori kewarganegaraan, kesejahteraan diartikan sebagai puncak dari evolusi hak-hak kewarganegaraan. Masyarakat Barat yang demokratis berkembang bermula dari hanya sebagian kecil saja yang mendapatkan hak-hak sipil, politik, dan sosial. Ketika hak-hak sipil mulai diterapkan secara lebih luas, maka pengertian kewarganegaraan menuntut untuk dipenuhi secara penuh akan hak-hak sosialnya. Seseorang tidak dapat dianggap sebagai anggota masyarakat yang penuh dan sederajat kalau kehidupannya dalam kemiskinan, menempati rumah yang tidak layak dihuni, kesehatannya tidak terjaga dengan baik, dan berpendidikan tidak memadai.

Negara kesejahteraan atau welfare state memiliki arti yang berbeda bagi semua orang. Oleh karenanya, Titmuss memberikan pengertian yang lebih terbuka pada kesejahteraan. Beliau menyarankan kriteria kesejahteraan sebagai suatu masyarakat yang secara terbuka menerima 
tanggung jawab kebijakan untuk mendidik dan melatih warga negaranya sendiri untuk memenuhi kebutuhannya akan tenaga dokter, perawat, pekerja sosial, ilmuwan, insinyur, dan sebagainya. Saran ini disampaikan agar negara-negara yang lebih miskin tidak kehabisan tenaga-tenaga ahli yang sangat diperlukan untuk pembangunan negara tersebut (Adi Fahrudin, 2012).

Konsep kesejahteraan telah berkembang menuju kesempurnaanya. Kesamaan berbagai konsep ini tertuju pada tujuan yang sama, yakni sebuah kondisi masyarakat yang semakin baik. Kondisi kesejahteraan ini merupakan sebuah gambaran yang diidealkan bersama, baik oleh pelaku usaha, organisasi massa, dewan perwakilan, pemerintah, maupun masyarakatnya.

\section{Kesejahteraan Menurut Al-Qur'an}

Kesejahteraan merupakan tujuan dari ajaran Islam dalam bidang ekonomi. Kesejahteraan merupakan bagian dari rahmatan lil alamin yang diajarkan oleh Agama Islam ini. Namun kesejahteraan yang dimaksudkan dalam Al-Qur'an bukanlah tanpa syarat untuk mendapatkannya. Kesejahteraan akan diberikan oleh Allah SWT jika manusia melaksanakan apa yang diperintahkannya dan menjauhi apa yang dilarangnya (Darsyaf Ibnu Syamsuddien :1994).

Ayat-ayat Al-Qur'an yang memberikan penjelasan tentang kesejahteraan ada yang secara langsung (tersurat) dan ada yang secara tidak langsung (tersirat) berkaitan dengan permasalahan ekonomi. Namun demikian, penjelasan dengan menggunakan dua cara ini menjadi satu pandangan tentang kesejahteraan.

\section{Qs. Al-Nahl : 97}

"Barangsiapa mengerjakan kebaikan, baik laki-laki maupun perempuan dalam keadaan beriman, maka pasti akan Kami berikan kepadanya kehidupan yang baik dan akan Kami beri balasan dengan pahala yang lebih baik dari apa yang telah mereka kerjakan."

Kesejahteraan merupakan jaminan atau janji dari Allah SWT yang diberikan kepada laki-laki ataupun perempuan yang beriman kepada-Nya. Allah SWT juga akan membalas berbagai amal perbuatan baik orang-orang yang bersabar dengan pahala yang lebih baik dari amalnya. Kehidupan yang baik adalah kehidupan yang bahagia, santai, dan puas dengan rezeki yang halal, termasuk didalamnya mencakup seluruh bentuk ketenangan apapun dan bagaimanapun bentuknya (Salim Bahreisy dan Said Bahreisy, 1988).

\section{Qs. Thaha 117-119}

"Kemudian Kami berfirman, "Wahai Adam, sungguh (ini) iblis musuh bagimu dan bagi istrimu, maka sekali-kali jangan sampai dia mengeluarkan kamu berdua dari surga, nanti kamu celaka. Sungguh, ada (jaminan) untukmu di sana, engkau tidak akan kelaparan dan tidak akan telanjang. Dan sungguh, di sana engkau tidak akan merasa dahaga dan tidak akan ditimpa panas matahari." Kesejahteraan menurut pengertian Al-Qur'an tercermin di Surga yang dihuni oleh Nabi Adam dan isterinya sesaat sebelum mereka bertugas sebagai khalifah di bumi. Kesejahteraan yang digambarkan dalam ayat ini menjamin adanya pangan, sandang, dan papan yang 
diistilahkan dengan tidak kelaparan, tidak merasa dahaga, tidak telanjang, dan tidak kepanasan oleh matahari. Sedangkan kebalikan darinya adalah kehidupan yang sempit, yakni jauh dari tentram dan tenang, selalu tidak puas, dadanya sesak dan gelisah walaupun lahirnya tampak mewah, serba ada, cukup pakaian dan tempat tinggalnya (Salim Bahreisy dan Said Bahreisy, 1988).

\section{Qs. Al-A'raf: 10}

"Dan sungguh, Kami telah menempatkan kamu di bumi dan di sana Kami sediakan (sumber) penghidupan untukmu. (Tetapi) sedikit kamu bersyukur." Pada ayat ini, Allah SWT mengingatkan kepada hambaNya untuk mensyukuri nikmat yang telah diberikan-Nya. Nikmat itu adalah sarana untuk mendapatkan kesejahteraan yang berupa bumi yang diciptakan-Nya untuk tempat tinggal, tempat memenuhi segala hajat hidup, menguasai tanah, hasil tanamannya, binatang-binatangnya, dan tambangtambangnya (Salim Bahreisy dan Said Bahreisy 1988).

4. Qs. Al-Nisa': 9

"Dan hendaklah takut (kepada Allah) orang-orang yang sekiranya mereka meninggalkan keturunan yang lemah di belakang mereka, yang mereka khawatir terhadap (kesejahteraannya). Oleh sebab itu, hendaklah mereka bertakwa kepada Allah dan hendaklah mereka berbicara dengan tutur kata yang benar."

Kesejahteraan dapat diperoleh hanya dengan ketaqwaan kepada Allah SWT dan juga berbicara secara jujur dan benar. Pada ayat ini, Allah SWT meminta kepada hamba-Nya untuk memperhatikan kesejahteraan generasi yang akan datang. Oleh karenanya harus dipersiapkan generasi yang kuat ketaqwaannya kepada Allah SWT. Bahkan Nabi Muhammad SAW juga melarang untuk memberikan seluruh hartanya kepada orang lain dengan meninggalkan ahli warisnya. Nabi SAW bersabda: "Sesungguhnya bila kamu meninggalkan ahli warismu dalam keadaan berkecukupan adalah lebih baik dari pada membiarkan mereka dalam keadaan miskin dan meminta-minta kepada orang lain (Salim Bahreisy dan Said Bahreisy, 1988).

\section{Qs. Al-Baqarah: 126}

"Dan (ingatlah), ketika Ibrahim berdoa: "Ya Tuhanku, jadikanlah (negeri Mekkah) ini, negeri yang aman, dan berilah rezeki berupa buah-buahan kepada penduduknya, yaitu diantara mereka yang beriman kepada Allah dan hari kemudian. Dia (Allah) berfirman: "Dan kepada orang kafir, Aku beri kesenangan sementara, kemudian akan Aku paksa dia ke dalam azab neraka dan itulah seburuk-buruk tempat kembali.”

Kesejahteraan hanya diperoleh dengan penyerahan diri sepenuhnya kepada Allah SWT. Ajaran Islam mengajarkan juga tentang konsep untuk berbagi, membagi nikmat, membagi kebahagian dan ketenangan tidak hanya untuk individu namun untuk seluruh umat 
manusia di seluruh dunia (Salim Bahreisy dan Said Bahreisy, 1988).

Kesejahteraan di Masa Rasulullah dan Para Sahabatnya

Ajaran ekonomi Islam tidak bisa dilepaskan dari sumber utamanya, yakni AlQur'an, Sunnah, dan khazanah Islam lainnya. Konsep-konsep ekonomi Islam yang didalamnya membahas tentang kesejahteraan individu, keluarga, masyarakat, dan negara telah tergambar secara jelas dalam ayat-ayat Al-Qur'an. Kesejahteraan dalam perspektif ekonomi Islam tidak hanya berhenti pada tataran konsep tetapi telah terwujud dalam praktek kehidupan Rasulullah dan para sahabatnya. Implementasi nilai kesejahteraan ini tidak hanya dirasakan oleh umat Islam tetapi juga umat non muslim, bahkan rahmat bagi seluruh alam hingga masa modern saat ini.

Ajaran Islam telah menjelaskan bahwa sesungguhnya tujuan dasar Islam adalah terwujudnya kesejahteraan baik di dunia maupun akhirat. Dalam prakteknya, Rasulullah SAW. Membangun suatu perekonomian yang dulunya dari titik nol menjadi suatu perekonomian raksasa yang mampu menembus keluar dari jazirah Arab. Pemerintahan yang dibangun Rasulullah SAW di Madinah mampu menciptakan suatu aktivitas perekonomian yang membawa kemakmuran dan keluasan pengaruh pada masa itu (Muhammad Sholahuddin, 2009).

Kegiatan ekonomi telah menjadi sarana pencapaian kesejahteraan atau kemakmuran. Nabi Muhammad SAW memperkenalkan sistem ekonomi Islam. Hal ini berawal dari kerja sama antara kaum Muhajirin dan Anshar. Sistem ekonomi Islam yang diperkenalkan, antara lain, syirkah, qirad, dan khiyar dalam perdagangan. Selain itu, juga diperkenalkan sistem musaqah, mukhabarah, dan muzara'ah dalam bidang pertanian dan perkebunan. Para sahabat juga melakukan perdagangan dengan penuh kejujuran. Mereka tidak mengurangi timbangan di dalam berdagang.

Semenjak hijrah ke Madinah, kehidupan telah banyak berubah. Para sahabat Nabi Muhammad SAW dari kaum Muhajirin bahu membahu dengan penduduk lokal Madinah dari kaum Anshar dalam membangun kegiatan ekonomi. Berbagai bidang digeluti oleh beliau dan para sahabatnya baik itu pertanian, perkebunan, perdagangan dan peternakan. Pasar-pasar dibangun di Madinah. Kebun-kebun kurma menghasilkan panenan yang melimpah. Peternakan kambing menghasilkan susu yang siap dipasarkan maupun hanya sekedar untuk diminum. Dalam sejarah, dikenal tokoh Islam yang terkenal dengan kekayaannya dan kepiawaiannya dalam berdagang dan berbagai bidang lainnya (Muhammad Husain Haekal, 1989).

Mereka adalah Abdurahman bin Awf, Abu Bakr, 'Umar bin Khattab, dan sebagainya. Mereka sadar akan dapat hidup di Madinah hanya dengan usaha mereka sendiri. Masyarakat Madinah terus berupaya meningkatkan aktivitas ekonomi dengan etos kerja yang tinggi. Ibadah dan kerja adalah dua jenis aktivitas ukhrawi dan duniawi yang menghiasi hari-hari mereka silih berganti. Pada awal tahun kedua Hijrah, Allah SWT sudah mewajibkan kaum muslimin membayar zakat. Tentu saja, zakat yang diwajibkan hanya bagi mereka yang 
telah berkecukupan (Zainal Abidin Ahmad, 1974).

\section{Kesejahteraan Menurut Ulama}

Ekonomi Islam telah menjadi pembahasan tersendiri pada masa modern sekarang ini. Kajian-kajian telah banyak dilakukan oleh para ulama mengingat pada masa awal pertumbuhan Islam, ekonomi Islam belum muncul sebagai sebuah disiplin keilmuan. Meskipun demikian, pondasi atau landasan dasarnya telah terealisasi di dalam sejarah Islam, sehingga hal inilah yang merupakan warisan yang terus menjadi sumber bagi berkembangnya nilai-nilai ekonomi Islam. Para ulama berperan besar di dalam memberikan penjelasan kepada para pelaku ekonomi dalam menjalankan kegiatan muamalahnya.

Sesungguhnya mengkaji ekonomi Islam bukanlah dominasi para ekonom. Tetapi kajian ekonomi Islam hendaknya dilakukan para pakar Islam yang menguasai pandangan Islam dengan segala aspeknya yang sempurna. Kemudian setelah ini, baru pengkajian berpindah pada para spesialis, spesialis perekonomian merumuskan sistem perekonomian dengan tetap membuat pandangan Islam sebagai landasan dan acuan dasar. Pandangan Islam meliputi syariahnya, yang berkait dengan sistem perekonomian maupun yang berkait dengan sosial kemasyarakatan (An Nabani, Taqyudin, 1996).

Al-Ghazali dalam Kitabnya Ihya' 'Ulum al-Din dan Al-Mustasfafi' 'Ilm al-Usul, mengartikan atau memaknai ilmu ekonomi sebagai berikut : Sarana untuk mencapai tujuan akhirat adalah dengan mencari nafkah (harta yang halal), semua ilmu itu bermanfaat dan dapat digolongkan menjadi dua kategori, yakni wajib dituntut secara Fard 'Ayn dan Fard Kifayah (termasuk ilmu ekonomi), dan tujuan hidup manusia adalah untuk mencapai kemaslahatan/kesejahteraan hidup (Abdur Rohman, 2010).

Berdasarkan deskripsi al-Ghazali diatas, pengertian ilmu ekonomi dapat diartikan sebagai ilmu yang mempelajari tentang upaya manusia dalam memenuhi kebutuhan (al-iktisab) yang wajib dituntut (fard kifayah) berlandaskan etika (syariah) dalam upaya membawa dunia ke gerbang kemaslahatan menuju akhirat. Definisi ini membawa kepada pemikiran bahwa ilmu ekonomi memiliki dua dimensi, yakni dimensi ilahiyah dan dimensi insaniyah.

Kesejahteraan menurut al-Ghazali adalah tercapainya kemaslahatan. Kemaslahatan sendiri merupakan terpeliharanya tujuan syara' (Maqasid alShari'ah). Manusia tidak dapat merasakan kebahagiaan dan kedamaian batin, melainkan setelah tercapainya kesejahteraan yang sebenarnya dari seluruh umat manusia di dunia melalui pemenuhan kebutuhankebutuhan ruhani dan materi. Untuk mencapai tujuan syara agar dapat terealisasinya kemaslahatan, beliau menjabarkan tentang sumber kesejahteraan, yakni: terpeliharanya agama, jiwa, akal, keturunan dan harta (Abdur Rohman, 2010).

Harta merupakan sarana yang penting dalam menciptakan kesejahteraan umat. Dalam hal tertentu harta juga dapat membuat bencana dan malapetaka bagi manusia. Al-Ghazali menempatkan urutan prioritasnya dalam urutan yang kelima dalam maqasid al-shari 'ah. Keimanan dan harta benda sangat diperlukan dalam 
kebahagiaan manusia. Namun imanlah yang membantu menyuntikkan suatu disiplin dan makna, sehingga dapat menghantarkan harta sesuai tujuan syariah.

\section{Kesejahteraan Menurut Ekonom Muslim}

Salah satu pengertian dari ilmu ekonomi adalah studi tentang bagaimana manusia bertingkah pekerti untuk mengorganisir kegiatan-kegiatan konsumsi dan produksinya. Oleh karenanya sistem ekonomi apapun termasuk ekonomi Islam yang diterapkan di dunia ini akan selalu berkaitan dengan tiga masalah utama perekonomian (The Three Fundamental and Interdependent Economic Problem). Ketiga masalah tersebut adalah barang apa dan berapa jumlahnya, cara dibuatnya dan untuk siapa distribusinya (Paul A. Samuelson dan William D. Nordhaus, 1989).

Konsep kesejahteraan tersebut dalam pandangan ekonomi Islam masih mencakup hanya dimensi materi. Ekonomi Islam menghendaki kesejahteraan itu juga mencakup keseluruhan unsur materi dan non materi (psikis). Hal ini disebabkan kepuasan manusia itu terletak pada unsur-unsur non materi. Kesejahteraan dalam fungsi matematisnya dapat dilihat dibawah ini (Hasan Aedy, 2011).

$$
\begin{array}{ll}
\mathrm{Ki} & =(\mathrm{MQ}, \mathrm{SQ}) \\
\mathrm{Ki} & =\text { Adalah kesejahteraan yang }
\end{array}
$$$$
\text { Islami }
$$

(Islamic Welfare)

$\mathrm{MQ}=$ Kecerdasan Material

(Material Quetient)

SQ $=$ Kecerdasan Spiritual

(Spiritual Quetient)

Dalam fungsi diatas dapat diketahui bahwa kesejahteraan yang optimal dapat tercapai apabila kecerdasan material dikontrol oleh kecerdasan spiritual mulai dari cara memperolehnya sampai kepada membelanjakan. Dalam prakteknya, mereka yang memiliki kecerdasan spiritual dapat menjadi tenteram, aman, dan sejahtera meskipun mereka tidak memiliki kecerdasan material. Sedangkan manusia yang hanya memiliki kecerdasan material tidak akan pernah mendapatkan kebahagiaan meskipun dengan harta yang melimpah. Kecerdasan Islami merupakan bagian fungsi dari kecerdasan material dan kecerdasan spiritual. Kecerdasan Islami dapat dicapai apabila hal-hal sebagai berikut dilakukan, yakni: benda yang dimiliki diperoleh dengan cara halal dan baik, bertujuan untuk ibadah, kualitas lebih dipentingkan daripada kuantitas, dan penggunaannya sesuai syariah.

Dalam kenyataannya, tidak semua manusia memiliki kecerdasan spirtual sebagaimana yang dijelaskan diatas. Adapun ciri-ciri manusia yang memiliki ciri-ciri kecerdasan adalah: Setia dan taat kepada Allah (habl min Allah), Setia dan konsisten memberikan manfaat atau pelayanan terbaik kepada sesama manusia (habl min al-nas), dan Setia dan konsisten dengan pemelihara alam dan lingkungan yang seimbang (habl min al- 'alamin) (Hasan Aedy, 2011).

Persaingan atau kompetisi dalam memanfaatkan sumber daya tetap akan didorong sepanjang hal dilakukan dengan sehat, meningkatkan efisiensi, dan membantu mendorong kesejahteraan manusia, yang merupakan keseluruhan tujuan Islam. Namun demikian, jika persaingan itu melampaui batas, mengakibatkan nafsu pamer, kecemburuan, mendorong kekejaman, dan kerusakan maka 
ia harus dikoreksi. Komitmen ini menuntut semua sumber daya di tangan manusia sebagai suatu titipan sakral dari Allah SWT dan harus dimanfaatkan untuk merealisasikan maqasid al-shari'ah, yang berupa pemenuhan kebutuhan pokok, sumber pendapatan yang terhormat, distribusi pendapatan dan kekayaan konsep ekonomi Islam untuk mewujudkan kesejahteraan masyarakat berdasarkan khazanah literatur Islam (M. Umer Chapra, 2000). Kepemilikan harta, meliputi kepemilikan individu, kepemilikan umum, dan kepemilikan negara. Pengelolaan harta harus mencakup pemanfaatan dan pengembangan harta (Muhammad Sholahuddin, 2009). Politik ekonomi Islam yang dilaksanakan oleh negara untuk menjamin tercapainya semua kebutuhan pokok (primer) setiap individu masyarakat secara keseluruhan, disertai jaminan yang memungkinkan setiap individu untuk memenuhi kebutuhan pelengkap (sekunder dan tersier) sesuai dengan kemampuan mereka yang merata, pertumbuhan dan stabilitas.

\section{Dampak Distribusi Tendapatan Terhadap Kesejahteraan Menurut Ekonomi Islam.}

Hidup diatas kemampuan pribadi sebagai personal maupun bangsa, melaksanakan kewajiban finansial sebagaimana yang ditunjukan oleh ajaran Islam dan meyakini sungguh-sungguh bahwa dunia saat ini bukan akhir cerita dari segala-galanya, Akan ada kehidupan baru setelah kehidupan di dunia. Islam menciptakan beberapa instrumen untuk memastikan keseimbangan pendapatan di masyarakat. Seperti zakat dan sedekah misalnya, instrumen ini di kedepankan untuk keseimbangan karena mengingat tidak semua orang mampu terlibat dalam proses ekonomi karena yatim piatu atau jompo dan cacat tubuh. Tetapi harus diingat zakat tidak ada sumbernya yang bertumpu pada tiga hal: profit perdagangan, pendapatan, dan gaji pekerja, dan aset perusahaan atau individu. Oleh karena itu, yang perlu diperhatikan adalah aktivitas ekonominya terlebih dahulu, baru dipompa kesadarannya untuk membayarkan zakat.

Dalam kehidupan memang akan terjadi perbedaan dan kesenjangan ekonomi atau rezeki diantara pelaku ekonomi, karena hal tersebut merupakan sunnatullah. Kondisi inilah yang secara religius akan menciptakan mekanisme ekonomi, bagi siapa mempunyai kelebihan rezki yang di berikan allah SWT menolong saudara/individu yang mempunyai kekurangan rezki atau harta, secara umum, Islam mengarahkan mekanisme berbasis moral spritual dalam pemiliharaan keadilan sosial pada setiap aktivitas ekonomi. Latar belakangnya karena ketidakseimbangan kekayaan adalah hal yang mendasari hampir semua konflik individu maupun sosial. Hal tersebut akan sulit dicapai tanpa adanya keyakinan pada prinsip moral dan sekaligus kedisiplinan dalam mengimplementasikan konsep moral tersebut. Ini adalah fungsi dari menterjemahkan konsep moral sebagai faktor endogen dalam perekonomian, sehingga etika ekonomi menjadi hal yang sangat membumi untuk dapat mengalahkan setiap kepentingan pribadi. Penekanan dalam konsep distribusi pendapatan adalah adanya hak Allah dan Rasul-Nya serta orang/muslim lain dari setiap pendapatan 
seorang muslim. Hal ini juga diarahkan sebagai bentuk dari takaful ijtimai (jaminan sosial) seorang muslim dengan keluarga dan dengan orang lain, sehingga menjamin terjadinya minimalisasi ketidaksetaraan pendapatan (uniequality income) dan keadilan sosial (sosial justice).

Sedangkan standar atau indikator kebutuhan dan batasan yang mendasari sistem distribusi pendapatan Islam adalah maqasid syariah. Sistematika hirarki yang dikembangkan fuqaha dalam memenuhi aspek-aspek tersebut mengacu pada skala prioritas dengan urutan berikut : 1) $A d$ daruriyyah : suatu skala kebutuhan yang berkaitan erat dengan kebaikan dan kepentingan dalam menjalani hidup di dunia dan akhirat, 2) Al-hajjiyyah : suatu skala kebutuhan yang berkaitan erat dengan kemudahan dan penghindaran kesulitan dalam menjalani hidup di dunia dan di akhirat, 3) At-tahsiniyyah : suatu skala kebutuhan yang berkaitan erat dengan kelengkapan dan kecakapan melaksanakan hidup di dunia dan akhirat.

Makanya hasil yang didapatkan oleh seseorang dalam usaha individu/kelompok untuk mengeluarkan hartanya dalam bentuk Zakat, Udhiyah, Musaadah, Jiwar, Infak, Wakaf dan lain sebaginya atas rezki yang diberikan Allah SWT. Apabila Implimentasi tersebut dilakukan dengan baik, akan tidak ada manusia yang mengalami diskriminasi terhadap sosial kemasyarakatan dan akan mengurangi tingkat kriminalitas di lingkungan masyarakat.

\section{KESIMPULAN}

Kesejahteraan di dalam perspektif ekonomi Islam adalah terpenuhinya kebutuhan materi dan non materi, dunia dan diakhirat berdasarkan kesadaran pribadi dan masyarakat untuk patuh dan taat (sadar) terhadap hukum yang dikehendaki oleh Allah SWT melalui petunjukNya dalam AlQur'an, melalui contoh dalam keteladanan Rasulullah SAW, dan melalui ijtihat dan kebaikan para ulama. Oleh karenanya kesejahteraan bukanlah sebuah cita-cita yang tanpa pengorbanan tetapi membutuhkan perjuangan yang terusmenerus dan berkesinambungan.

\section{DAFTAR PUSTAKA}

Aedy, Hasan. Teori dan Aplikasi Ekonomi Pembangunan Perspektif Islam Sebuah Studi Komparasi. Yogyakarta: Graha Ilmu, 2011.

Ahmad, Zainal Abidin. Negara Adil

MakmurMenurut Ibnu Siena. Jakarta: Bulan Bintang, 1974.

Arafat, Yasir. Undang-Undang Dasar Republik Indonesia 1945 \& Perubahannya Ke I, II, III, \& IV. Permata Press, tt.

Chapra, M. Umer. Islam dan Tantangan Ekonomi. Jakarta: Gema Insani Press, 2000 .

Dampriyanto. Undang-Undang Dasar Negara Republik Indonesia Tahun 1945. Sidoarjo: Masmedia Buana Pustaka, 2009.

Fahrudin, Adi. Pengantar

Kesejahteraan

Sosial. Bandung: Refika Aditama.

Haekal, Muhammad Husain. Sejarah Hidup Muhammad. Jakarta: Litera Antar Nusa, 1989.

Hafidudin, Didin dan Hendri Tanjung. Manajemen Syariah dalam Praktek. Jakarta: Gema Insani Press, 2003. 
Hamidi, M. Lutfi. Jejak-Jejak Ekonomi Syariah.Jakarta: Senayan Abadi Publising, 2003.

Hikmat, Harry. Strategi Pemberdayaa

Masyarakat. Bandung: Humaniora

UtamaPress, 2010.
Hilal, Mushaf Al Azhar Al Quran dan Terjemahannya. Bandung: Penerbit Hilal, tt. 